\title{
THE FEASIBILITY OF A HOME CARE MANAGEMENT MODEL BASED COACHING INTERVENTION ON INDONESIAN CAREGIVERS' OUTCOMES OF RELATIVES WITH SCHIZOPHRENIA
}

\author{
Jenny Marlindawati Purba1, R H Simamora², E D Ginting3
}

1. Department of Psychiatric and Community Nursing, Faculty of Nursing, Universitas Sumatera Utara, Medan, Indonesia

2. Department of Fundamental and Medical Surgical Nursing, Faculty of Nursing, UniversitasSumatera Utara, Medan, Indonesia

3. Faculty Psychology, Universitas Sumatera Utara, Medan, Indonesia

\begin{abstract}
Caring for schizophrenia is a challenge and a burden for caregiver. In fact, family caregivers did not know how to care schizophrenia at home. A home management care base coaching is urgently needed. It can be used as a basis for nurses to assist caregivers in caring for persons with schizophrenia. The study aimed to determine the feasibility of a home care management model base coaching for family caregivers of persons with schizophrenia. The pilot study was two groups pre-test and post-test quasi-experimental design. Thirty family caregivers who met the inclusion criteria were assigned into experimental and control group (each group 15 persons) using purposive sampling. The data were collected using the Chiang Mai Psychiatric Caregiving Scale, the Zarit Caregiver Burden Scale and the Schizophrenia Caregiver Quality of Life questionnaire. The participants who received home care management model based coaching interventions reported significant improvement in caregiving skills $(p<0.05)$, increased quality of life $(p<0.05)$ and decreased level of burden care $(p<0.05)$ than those receiving the routine care. The pilot study revealed that home care management model based coaching intervention was feasible used as nursing intervention to improve caregivers' outcomes in providing care for relatives with schizophrenia at home
\end{abstract}

Keyword : Caregivers' outcomes, coaching, home care management model, schizophrenia

\section{ABSTRAK}

Merawat anggota keluarga dengan skizofrenia merupakan tantangan dan beban bagi caregiver. Pada kenyataannya, caregiver tidak mengetahui cara merawat anggota keluarga dengan skizofrenia di rumah. Oleh karena itu, sebuah model manajemen perawatan rumah berbasis coaching sangat dibutuhkan. Model ini dapat digunakan sebagai dasar bagi perawat untuk membantu caregiver memberikan perawatan bagi keluarga dengan skizofrenia di rumah. Studi ini bertujuan untuk melihat kelayakan model manajemen perawatan rumah berbasis coaching. Studi ini menggunakan desain kuasi eksperimen dengan rancangan dua kelompok pre-test dan post-test. Dengan menggunakan teknik purposive sampling sebanyak tiga puluh partisipan yang memenuhi kriteria inklusi dibagi ke dalam kelompok intervensi $(n=15)$ dan kelompok kontrol $(n=15)$. Pengumpulan data dilakukan menggunakan kuesioner skala caregiving psikiatri Chiang Mai, skala beban caregiver,Zarit dan kuesioner kualitas hidup caregiver yang merawat klien skizofrenia. Partisipan dalam kelompok intervensi yang menerima model manajemen perawatan rumah berbasis coaching menunjukkan peningkatan yang bermakna dalam keterampilan merawat $(p<0,05)$, peningkatan kualitas hidup $(p<0,05)$ dan berkurangnya tingkat beban yang dirasakan dalam merawat $(p<0,05)$ dibandingkan dengan partisipan yang hanya menerima perawatan rutin saja. Studi pilot ini menunjukan bahwa model manajemen perawatan rumah berbasis coaching layak digunakan sebagai intervensi keperawatan untuk meningkatkan outcome caregiver dalam merawat anggota keluarga dengan skizofrenia di rumah.

Kata kunci: Outcome caregiver, coaching,model manajemen perawatan rumah, skizofrenia 


\section{BACKGROUND}

Schizophrenia is a chronic mental disorder that impairs the functioning of a person's thought personality, language, emotions, and capability to perceive rationale accurately (Herzog \& Varcarolis, 2010). It is a common psychotic illness and is often considered as a serious mental illness. This is because people withschizophrenia often show poor longterm outcomes in social settings and in fields of specialization (Viron, Baggett, Hill, \& Freudenreich, 2012).

The onset is in early adulthood between the ages of 15 and 35 . In males, it begins 4-5 years earlier (15-25 years) than in females (25-35 years) (Wright \& Kraus, 2012 cited in Purba, Suttharangsee, \& Chaowalit, 2015). In Medan, Indonesia, there are increasing numbers of people with schizophrenia living in the community. In 2016, the number of schizophrenia patients was 14.838 persons. The number of patients visiting the outpatient department was 3781.

Schizophrenia does not cause disturbances for the patients only but also their family. Family caregivers experience a series of conflicts and tend to show emotional responses such as fear of violence, stigma, frustration, sadness, feeling angry, and timelessness (Dangdomyouth, Stern, Oumtanee, \& Yunibhand, 2008; Papastavrou, Charalambous, Tsangari, \& Karayiannis, 2010). Family caregivers also suffer from financial problems and lack of knowledge, in particular information about schizophrenia (Small, Harrison, \& Newell, 2010). The experience of caring for a long period of time can reduced the quality of life, and has significant impacts on mental health and functional status of the caregiver (Caqueo-Urizar, GutierrezMaldonado, Ferrer-García, \& DarrigrandeMolina, 2011). Using the ZBI, a study conducted by Shamsaei, Cheraghi, and Bashirian (2015) found that $7.6 \%$ of the caregivers experienced "no to low" burden, $23.5 \%$ "mild to moderate", $41.8 \%$ "moderate to severe" and $27.1 \%$ severe" burden. The mean average score of the responses to $\mathrm{ZBI}$ was 51.73 ( $\mathrm{SD} \pm 18.23)$.
To improve the caregiver's caring ability at home, mental health nurse have an obligation to help caregivers to meet the needs of caring for and sharing experiences with other caregivers who had similar experiences with them (Kertchok, Yunibhand, \& Chaiyawat, 2011). Moreover, Tungpunkom, Napa, Chaniang, and Srikachin (2013) stated that caregivers need to apply various skills to provide effective care for their loved ones by confronting with aggressive behavior, psychotic symptoms, as well as other facets of their everyday life, such as education, work, socialization, life skills, and other aspects of daily living. In addition, along with the development of science and technology, as well as changes in the health paradigm that focuses on preventive and promotion efforts, so that the patient care has move into home care (Zen, 2007). Caregiving skills training intervention needs to be developed beyond the existing psychoeducation group, and caregivers claim their needs and concerns about the long term care mental health facility and seek sustainable help for their ill relatives (Tungpunkom et al., 2013). Right now, there is no a home care intervention conducting in Indonesia. Most nursing intervention for family particularly caregivers of schizophrenia persons still focus on psychoeducation, support group, cognitive behavior therapy. Therefore, a home care management intervention can be used as one of the most effective interventions to help caregiver's provide caring independently for their loves one with schizophrenia (Chien, Lee, \& Phill, 2010).

Home care management base coaching model intervention is very important because most schizophrenic patients return home after discharge from hospital (Chien et al., 2010). It was developed based on the coaching process derived from Thorpe and Clifford (2003). Coaching is a strategy that can help caregiver to improve their ability in caring for persons with schizophrenia (Kertchok et al., 2011: Caqueo-Urizar et al., 2011). 


\section{METHOD}

A two group pretest-posttest quasi-experimental research design was employed in order to examine the feasibility of the home care management model based coaching to improve the caregivers' outcomes in caring for relatives with schizophrenia. The pilot study was conducted between Augusts to November 2017.

The participants were the primary caregivers of persons with schizophrenia who attended Outpatient-Department in psychiatric hospital, Medan Indonesia. Thirty participants met the inclusion criteria: (1) age 18 to 65 years old, (2) mentally alert, (3) able to understand and read Bahasa Indonesia, (4) live with and care for a family member who at recruitment has met the DSM-IV-TR diagnostic classification for schizophrenia for at least 1 year.

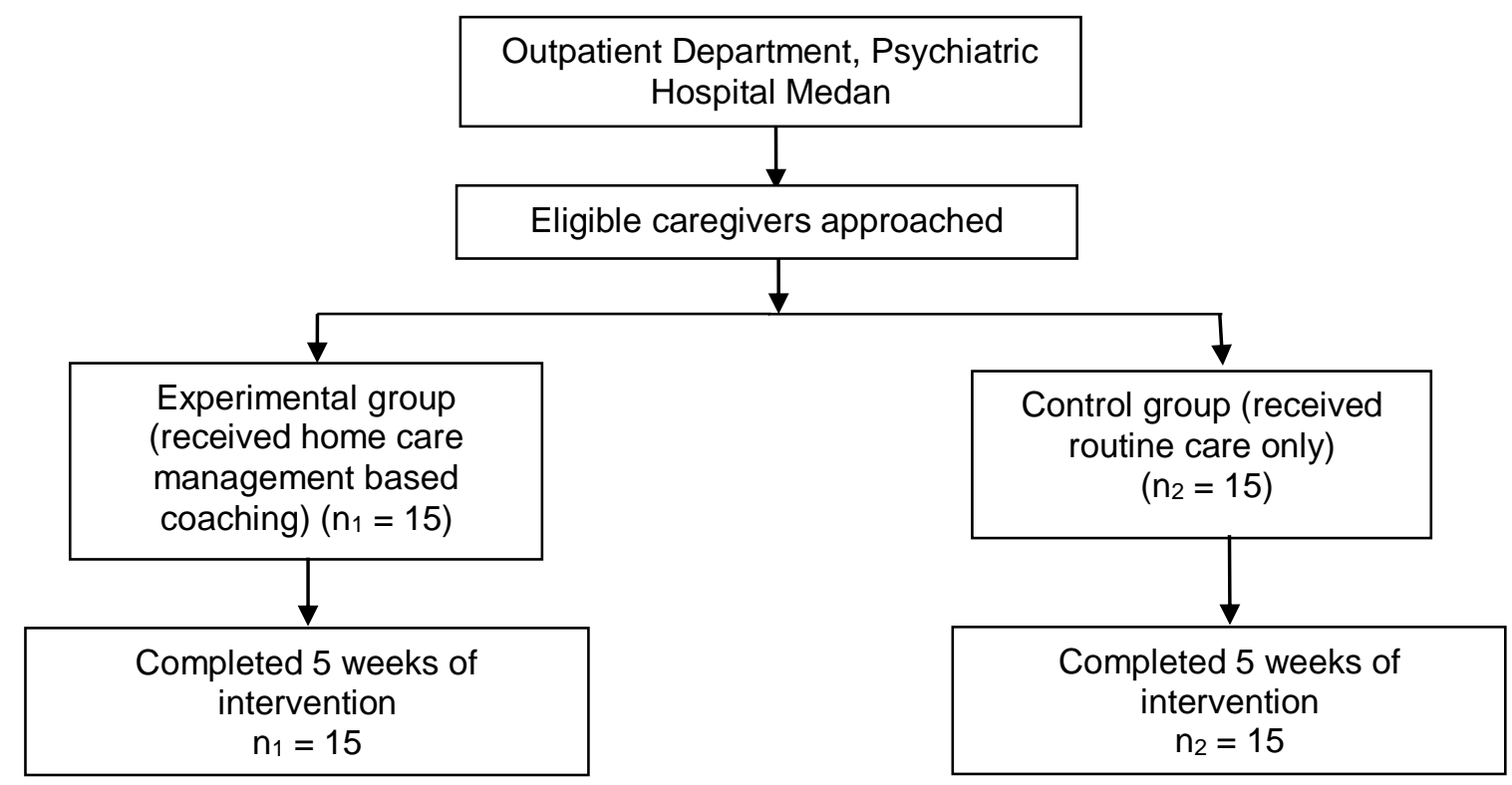

Figure 1. The flow diagram of participants during data collection at Outpatient Department, Psychiatric Hospital

The researchers collected the data in the Outpatient Department. The participants who were willing to participate in this study and signed of informed consent were assigned into either the experimental or control groups. The participants in the experimental group received the home care management model based coaching that lasted around 1 to 2 hours/week. This intervention was conduct for 5 weeks. In this study, the home care management model based coaching intervention consisted of teaching about schizophrenia, educating on how to provide effective care for persons with schizophrenia, home visits, and a telephone follow-ups to evaluate their performance regarding care, and help improve their skills and quality of life as well as reduce the burden level for future care. Finally, the researcher assessed the participants' success in reaching desired objectives. Participants were also asked if they had any questions or new ideas regarding the home care management based coaching activities. Meanwhile, participants in the control group received routine care only that provided by psychiatric nurses at outpatient department.

The Chiang Mai Psychiatric Caregiving Scale (CPCSS) was used to measure the caregivers' skills in caring for the schizophrenic psychiatric patient at home (Suriyong, Tungpunkom \& Chalinee, 2008). The CPCSS was composed a 50item list of caregiving skills, and used a Likert-type scale of 0 (the patient can do it by himself or no condition occurs) to 3 (done all the time). This scale was translated into Indonesian and validated on the study's Indonesian caregivers with 
a content validity of 0.8 and a reliability of 0.82 .

The Zarit Burden Interview (ZBI) is one tool to provide a comprehensive assessment of both objective and subjective burden. The ZBI is commonly used to measure the burden level of schizophrenia caregivers and has been validated in many countries in the world. The ZBI consists of 22 items rated on a four-point Likert scale that ranges from 0 (never) to 4 (nearly never). The total score range from 0 to 88 . Higher scores indicate the higher level of burden care. In the study of Seng et al. in Singapore (2010), the Cronbach's alpha value was 0.93 and the test-retest reliability was 0.89 . The instrument was validated by three experts with a content validity of 0.9 . The overall Cronbach's alpha was 0.95 .

The Schziophrenia Caregiver Quality of Life (S-CGQoL) is a selfadministered instrument to measure the quality of life of caregivers of individuals with schizophrenia (Richieri, Boyer, Reine, Loundou, \& Auquier, 2011). It contains 25 items describing seven dimensions (psychological and physical well-being, psychological burden and daily life, relationship with spouse, relationship with psychiatric team, relationship with family, relationship with friend, and relationship with material burden). The instrument was translated from original English version to an Indonesian version by using three translators. The S-CGQoL was validated by three experts with a content validity of 0.9 . The higher scores indicate higher quality of life of caregivers. The overall Cronbach alpha of The S-CGQoL was 0.93 .

Ethical approval for the study was granted by the ethic committee Faculty of Nursing, University of Sumatera Utara (Number 1570/IX/SP/2018), Medan Indonesia. Signed informed consent was obtained from 30 participants before intervention, and confidentiality was maintained.

The independent t-test test was applied to ascertain whether there was a significant difference pre and postintervention between the control and experimental groups. The Paired test was carried out to test significant difference within the groups. The level of significance was set at $p<0.05$.

\section{RESULTS}

At pretest there was no difference between skill and quality of life of the caregiver in intervention group and control group. The mean score of the caregivers' skill in intervention and control group was $94.13(\mathrm{SD}=16.39)$ and $85.60(\mathrm{SD}=12.82)$ respectively. The mean score of caregivers' burden in experimental group was $47.73 \quad(\mathrm{SD}=4.56)$ and 46.67 $(S D=5.23)$ in control group. Meanwhile, the mean score of the caregivers' quality of life in experimental and control group was $72.27(\mathrm{SD}=11.42)$ and 78.33 (12.34) respectively. The independent test t-test showed no differences between experimental and control groups (Table 1).

Table 1. Pre-test score of caregiving skills, burden and quality of life

\begin{tabular}{|c|c|c|c|c|c|c|}
\hline \multirow[t]{2}{*}{ Variable } & \multicolumn{2}{|c|}{$\begin{array}{c}\text { Experimental } \\
(\mathrm{n}=15)\end{array}$} & \multicolumn{2}{|c|}{$\begin{array}{c}\text { Control } \\
(n=15)\end{array}$} & \multirow[t]{2}{*}{$t$} & \multirow[t]{2}{*}{$p$} \\
\hline & $\mathbf{M}$ & SD & $\mathbf{M}$ & SD & & \\
\hline Caregiving skills & 94.13 & 16.39 & 85.60 & 12.82 & 1.59 & 0.12 \\
\hline Burden & 47.73 & 4.56 & 46.67 & 5.23 & 0.59 & 0.56 \\
\hline Quality of Life & 72.27 & 11.42 & 78.33 & 12.34 & -1.39 & 0.17 \\
\hline
\end{tabular}

The mean score of the caregivers' skills during pre-test and posttest in intervention group was 94.13 $(S D=16.39)$ and $113.60 \quad(S D=15.45)$ respectively. The mean score of caregivers' burden before and after intervention in experimental group was $47.73(\mathrm{SD}=4.56)$ and $38.80 \quad(\mathrm{SD}=7.79)$ respectively. Furthermore, the mean score of caregivers' quality of life at pre-test and post-test was $72.27 \quad(\mathrm{SD}=11.42)$ and $100.67(S D=7.68)$ respectively. Paired $t-$ test showed that the mean score of caregivers' skill and quality of life increased following intervention ( $\mathrm{t}=-5.83$; $\mathrm{p}<0.01$ and $\mathrm{t}=-8.56 ; \mathrm{p}<0.01)$. Moreover, 
the mean score of caregivers' burden level in experimental group decreased after completion of intervention $(t=5.79, \quad p$ $<0.01$ ) (Table 2).

Table 2. Comparisons of pre-test and post-test scores of caregiving skills, burden and quality of life within experimental group $(n=15)$

\begin{tabular}{|c|c|c|c|c|c|c|}
\hline \multirow{2}{*}{ Variable } & \multicolumn{2}{|c|}{ Pre test } & \multicolumn{2}{|c|}{ Post test } & \multirow[b]{2}{*}{$t$} & \multirow[b]{2}{*}{$p$} \\
\hline & $\mathbf{M}$ & SD & $\mathbf{M}$ & SD & & \\
\hline Caregivin & 94.13 & 16.39 & 113.60 & 15.45 & -5.83 & 0.000 \\
\hline Burden & 47.73 & 4.56 & 38.80 & 7.79 & 5.79 & 0.000 \\
\hline Quality of Life & 72.27 & 11.42 & 100.67 & 7.68 & -8.56 & 0.000 \\
\hline
\end{tabular}

The independent t-test was used to measure the average mean of caregivers' skills, burden and quality of life scores in experimental and control groups at post-test (Table 3). The mean score of caregivers' skill and quality of life at posttest in experimental group was significantly higher than those of in control group ( $\mathrm{t}=4.72, \mathrm{p}<0.01$ and $\mathrm{t}=4.49, \mathrm{p}<0.01$ ). Meanwhile, the mean score of caregivers' burden in caring for family members with schizophrenia after obtaining home care management base coaching model intervention is significantly lower than those in control group $(\mathrm{t}=-3.80, \mathrm{p}<0.01)$.

Table 3. Comparisons of post-test scores of caregiving skills, burden and quality of life between experimental and control group $(n=15)$

\begin{tabular}{lcccccc}
\hline \multirow{2}{*}{ Variable } & \multicolumn{2}{c}{$\begin{array}{c}\text { Experimental group } \\
(\mathbf{n}=\mathbf{1 5})\end{array}$} & \multicolumn{2}{c}{$\begin{array}{c}\text { Control group } \\
(\mathbf{n}=\mathbf{1 5})\end{array}$} & \multirow{2}{*}{$\boldsymbol{t}$} & \multirow{p}{*}{$\mathbf{p}$} \\
\cline { 2 - 5 } & $\mathbf{M}$ & $\mathbf{S D}$ & $\mathbf{M}$ & $\mathbf{S D}$ & & \\
\hline Caregiving skills & 113.60 & 15.45 & 88.60 & 13.50 & 4.72 & 0.000 \\
Burden & 38.80 & 7.79 & 46.87 & 2.64 & -3.80 & 0.001 \\
Quality of Life & 100.67 & 7.68 & 79.47 & 16.58 & 4.49 & 0.000 \\
\hline
\end{tabular}

\section{DISCUSSION}

Results of this study showed that there was no significant difference in mean score of caregivers' skill, burden and quality of life between intervention group and control group during pre-test. However, there was a significant difference in mean score of caregivers' skills, burden and quality of life in the intervention group over the control group after completing the home care management basecoaching model intervention.

Coaching is one of the strategies used by nurses to improve caregivers' skills in caring for family members whom experience schizophrenia. A previous study by Purba, Suttharangsee and Chaowalit (2017) showed that the coaching method clearly indicates positive effects on caregivers' outcomes in performing care for their relatives with schizophrenia. Furthermore, they claimed that caregivers in the coaching group showed significantly higher knowledge levels ( $F=85.77, p<0.001)$, lower levels of negative attitudes towards schizophrenia ( $F=13.22, p<0.001)$, and higher skill levels $(F=22.94, p<0.001)$ than those in the routine care group.

This home care management based coaching model intervention was developed to help caregivers care for family members suffering from schizophrenia. Home care management base coaching uses several methods in its implementation to help caregivers include discussion, watch videos, training for caregiver and observation patients, demonstration, and the use of phone. While the media include LCD, white boards, and videos about schizophrenia, the format of the plan, plain paper, a guide book, and the use of pens.

In this study, all caregivers were active in discussion forums. They recounted the experiences and obstacles they found in caring for family members with schizophrenia. The problem often found by caregivers was the difficulty in administering medications regularly to the patients. They say that patients often 
refuse to take medicine because of boredom and declare themselves healed. In addition, most of the time caregiversare also faced with the emotions of patients who are not stable. In general, family members who experience schizophrenia have low motivation in doing daily activities. So caregivers are often annoyed and are sometimes frustrated with these situations. Therefore, researchers facilitate caregivers and patient in overcoming this problem. The researchers taught caregivers and agreed on the time of administration at 8 am after breakfast and $7 \mathrm{pm}$ after dinner. The researchers also reminded caregivers to record the time to make it easier for them to remind patients to take the medicine correctly in terms of time, medicine, way, dose, person, and sustainable.

The home visit activity conducted by the researcher provided significant changes to caregiver and schizophrenic patients. They are very happy to get a visit from the researchers. Caregivers freely express their life experiences with family members who suffer from schizophrenia. They are more open to telling the condition of the sick family members. Caregiver is also passionate in demonstrating what has been taught in previous meetings.

It can be concluded that home care management base coaching models intervention have a positive impact on improving caregiver skills and quality of life and help reduce maintenance burden. Triwibowo (2012) describes the benefits of home patient care are as follows: 1) the service will be more perfect, holistic and comprehensive; 2) a more professional service; 3) independent nursing services can be applied under the auspices of the legal and ethical aspects of nursing; and 4) patient needs for care can be met so they are more comfortable and satisfied with professional nursing care.

Home care management using coaching approach has a positive impact on improving cognitive function of schizophrenic patients and enhancing the skills and quality of life of caregiver as the primary carer for the sick family members at home. Research conducted by Friedman-Yakoobian, Mueser, Giuliano,
Goff, and Seidman (2009) reported that coaching can be used as a family-friendly method for dealing with family members with cognitive impairment and reducing the impact of cognitive impairment on social functioning of schizophrenia. In their study, it was found that coaching can be used as one of the methods to provide treatment to help family members who experience schizophrenia adapting to their cognitive decline.

In a randomization controlled trial study on the impact of in vivo feedback on ability to improve parenting skills, Shanley and Niec (2010) reported that positive caregiver skills were found in the group of parents receiving coaching programs which significantly increased compared with those who did not. In addition, there was a significant difference in positive parenting skills between the trained group and the control group. The results show that the effects of coaching can be important factors for changing caregiver's behavior and can show as a predictor of skill development from early-stage skills. It can be concluded that home care management model based coaching have a positive impact to improve caregivers' skills, quality of life and could reduce the level of burden care.

\section{CONCLUSION}

There were significant differences in caregivers' skills, burden and quality of life between the participants in the experimental group who received home care management model based coaching and the control group who received routine care only $(\mathrm{t}=4.72, \mathrm{p}<0.05 ; \mathrm{t}=-3.80, \mathrm{p}<$ 0.05 and $t=4.49, p<0.05$, respectively). The study had limitations such as it did not apply the random sampling and the followup using telephone calls were not reflect the real evaluation due to a lack observation and it could make the measurement bias. This study can be used as evidence based for psychiatric nurses to improve caregiver outcomes in performing effective care for their relatives with schizophrenia. This study presents that home care management base coaching can be applied by psychiatric nurses to help both caregivers and their 
relatives. The nurses also can use this model either in a psychiatric hospital and community setting. The health policy maker should pay attention and consider to use this model to develop psychosocial intervention to prevent Indonesia caregivers perform "pasung" (a form of traditional physical restraint) to their loves ones with schizophrenia. The results also indicate that it is necessary to use larger sample size and longer follow-up in the further research to evaluate the sustainability of caregivers' outcomes.

\section{ACKNOWLEDGEMENT}

The study was supported by a Scholarship awarded from Directorate General of Research and Development Ministry of Research, Technology and Higher Education with the Institute of Research University of Sumatera Utara Number : 148/UN5.2.3.1/PPM/KP-DRPM/ 2018.

\section{REFERENCES}

Caqueo-Urizar, A,, Gutierrez-Maldonado, J., Ferrer-Garcia M, PenalozaSalazar, C., Richards-Araya D., \& Cuadra-Peralta. (2011). Attitudes and burden in relatives of patients schizophrenia in a middle income country. BMC Family Practice, 12, 101-112.

Chien, W.T., Lee, I.Y.M., \& Phill, M. (2010). The schizophrenia care management program for family caregivers of Chinese patients with schizophrenia. Psychiatric Service, 61(3), 317-320.

Dangdomyouth, P., Stern, P. N., Oumtanee, A., \& Yunibhand, J. (2008). Tactful monitoring: How Thai caregivers manage their relative with schizophrenia at home. Issues Mental Health Nursing, 29(1), 37-50.

Friedman-Yakoobian, M. S., Mueser, K. T., Giuliano, A., Goff, D. C., \& Seidman, L.J. (2009). Familydirected cognitive adaptation for schizophrenia. Journal of Clinical
Psychology, 65(8), 854-867. doi: 10.1002/jclp.20611

Herzog, E. A., \& Varcarolis, E. M. (2010). Schizophrenia. In E. M. Varcarolis \& M.J. Halter (Eds.), Foundations of psychiatric mental health nursing: $A$ clinical approach (pp. 306-318). St.Louis Missouri: Saunders, Elsiever Inc.

Kertchok, R., Yunibhand, J.,\& Chaiyawat, W. (2011). Creating a new whole: Helping families of people with schizophrenia. International Journal of Mental Health Nursing, 20(1), 3846. doi: 10.1111/j.14470349.2010.00706.x

Papastavrou, E., Charalambous, A., Tsangari, H., \& Karayiannis, G. (2010). The cost of caring: The relative with schizophrenia. Scandinavia of Journal Caring Science, 24(4), 817-823.

Purba, J.M., Suttharangsee, W, \& Chaowalit A. (2015). Effectiveness of a coaching program for enhancing knowledge, attitude and skills on family caregivers in caring for persons with schizophrenia (Doctoral dissertation, the Prince of Songkla University, Thailand). Retrieved from kb.psu.ac.th/psukb/bitstream/2016/1 0671/1/409412.pdf

Purba, J.M., Suttharangsee, W, \& Chaowalit A. (2017). Effectiveness of a coaching program for family caregivers of persons with schizophrenia: A randomized controlled trial. Walailak Journal of Science\& Technology, 14(1), 11-24.

Richieri, R., Boyer, L., Reine, G, Loundou, A, \& Auquier, P. (2011). The schizophrenia caregiver quality of life questionnaire

(S-CGQoL): Deveopment and validation of an instrument to measure quality of life of caregivers of individuals with schizophrenia. Schizophrenia 
Research, 126, 192-201.

Seng, B.K., Luo, N., Ng, W.Y., Lim, J., Chionh, H.L., \& Goh, J. (2010). Validity and reliability of the Zarit Burden Interview in assessing caregiving burden. ANNALS Academy of Medicine Singapore, 39,758-763.

Shamsaei, F., Cheraghi, F., \& Bashirian, S. (2015).Burden on family caregivers caring for patients with schizophrenia. Iran of Journal Psychiatry, 10(4), 239-245.

Shanley J.R, \& Niec, L.N. (2010). Coaching parents to change: The impact of in vivo feedback on parents' acquisition of skills. Journal of Clinical Children \& Adolescent Psychology, 39(2), 282-287. doi: $10.1080 / 15374410903532627$

Small, N., Harrison, J., \& Newell, R. (2010).Carer burden in schizophrenia: Considerations for nursing practice. Mental Health Practice, 14(4), 22-25.

Suriyong, J., Tungpunkom, P., \& Chalinee, S. (2008). Effect of the family caregiving program on caregiving skills among caregivers of patients with schizophrenia. Nursing Journal, 35, 97-106.

Thorpe, S., \& Clifford, J. (2003). The coaching handbook: An action kit for trainers \& managers. Kogan Page: London.

Triwibowo, C. (2012). Home care: Konsep kesehatan masa kini. Yogyakarta: Nuha Medika.

Tungpunkom, P., Napa, W., Chaniang, S., \& Srikachin, P. (2013). Caregiving experiences of families living with persons with schizophrenia: A systematic review. JBI Library of Systematic Reviews and Implementation, 11(8), 415-564.
Viron, M., Bagget, T., Hil, M., \& Freudenreich, O. (2012). Schizophrenia for primary care providers: How to contribute to the care of a vulnerable patient population. American Journal Medicine, 125(3), 223-230.

Zen. M. (2007). Home care the opportunity for nursing profession. [the Indonesia language]. Poltekes Kemenkes. Malang. 